\title{
The Academic Use of Smartphone in English Classes
}

\author{
Muchlas Suseno
}

\begin{abstract}
Ample researches about smartphone use problems have been conducted for years recently. Despite it, however, researches of academic use of smartphone is limited, particularly related to English classes in Indonesian context. This research was conducted to scrutinize how teachers of English take benefits of the smartphone use in the delivery of both teaching and testing activities. Sample comprised 129 teachers derived from three school clusters i.e., Junior Secondary, General Senior Secondary, and Vocational Senior Secondary schools in the greater city of Jakarta. To confirm it, data of student's practice of the smartphone use to learn English was also scrutinized. For that purpose, diverse students from the three school clusters were involved. The research reveals the findings, such as (1) all teachers are familiar with the features and application available in the smartphone, (2) all teachers utilize the available application to blend the delivery of teaching activities, but kinds and numbers of the application vary, (3) reading is the most preferred skills to deliver using smartphone, (4) almost all teachers utilize the available application to assess student's learning achievement, and google application is the most preferred choice, (5) in addition to teaching and testing, all teachers utilize smartphone to motivate students to learn English, but kinds of application is limited, (6) rule reinforcement is significantly important to enact as far as smartphone use during schools hours is concerned. This research implies that blended teaching is obligatory in the millennial age nowadays.
\end{abstract}

Keywords: academic smartphone use, teaching English

\section{INTRODUCTION}

\section{Background}

Based on a survey conducted by emarketer, the growth of smartphone use in Indonesia is remarkably increasing very fast in the last six years recently. It reaches amount up to 103 million in 2018. It grows around 4 times as many as the number in 2013 [1]. In the other end, however, The Asian Parent Insight in collaboration with Samsung Kidstime report their survey that there is a mismatch between parent's hope and the actual use of smartphone, in which $81 \%$ parents hope their children to use the smartphone for academic purposes, but unfortunately, it's only $57 \%$ implemented [2]. In addition, the survey concludes that $92 \%$ parents are worried about their children in using the smartphone. Thus, there exists a big gap between the hope and the reality. This article is written to report a verification of such a mismatch particularly with the context of secondary schools in Indonesia. It starts with a brief description why this research is significantly urgent to be conducted together with the formulation of research questions followed by literary review. Next is a brief description about the research methodology and ends with

Revised Manuscript Received on 14 August, 2019.

MuchlasSuseno, Master Program of English Language Education, UniversitasNegeri Jakarta, Rawamangun Jakarta Indonesia (Email: muchlas-suseno@unj.ac.id) the research result together with the discussion and conclusion.

\section{The urgency of the research}

Ample researches about smartphone use problem have been conducted in various places across nations. Similarly, researches about academic smartphone use have also been undertaken, but almost all of them derived the data from the angle of students [3], [4]. In other words, researches on academic smartphone involving teachers are likely scant.

In their research $\mathrm{Ng}$ et al., [4] examined how students use the smartphone to support their school-related learning and claimed the higher use of smartphone, the lower academic achievement students could gain. This unavoidably worsens the situation in which, as noted, parents are worried with the smartphones at the hands of their children. Despite it, though, under any circumstance parents should indispensably stay calm to support their children in the learning processes, for this they could leave it at the hands of teachers.

When this is the case, they might certainly put high expectation that teachers set tight rules of disciplines as far as smartphone use at schools is concerned. However, parents should continuously pay high concern with the smartphone use as children generally tend to break the rules and use their smartphones not for academic purposes but for games [5]. Thus, this article is necessarily urgent to report how teachers have benefited the smartphones for academic purposes and by so doing it may convince parents that their children apply the smartphones at schools purposefully for academic activities.

\section{Formulation of research questions}

To elaborate it, four focal questions are raised and, as noted, they are mainly viewed from the teacher's perspectives, such as practical purposes of applying program applications or Apps in the smartphones, their preferred Apps to deliver teaching and testing activities, as well as the use of Apps to motivate students to learn. These perspectives are formulated into four questions as follows:

1) To what extent do teachers of English benefit the program applications or Apps available in the smartphones?

2) What applications do they use in the teaching delivery?

3) What applications do they use to administer class assessment?

4) To what extent do they benefit smartphones to motivate students to learn?

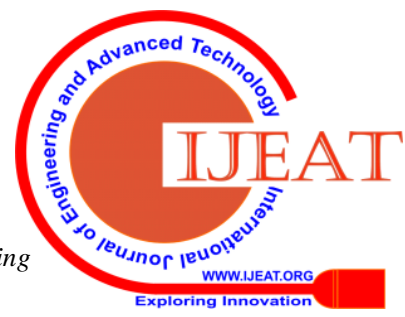




\section{LITERARY REVIEW}

Unlike the old-fashioned cellular phones, smartphones are incredibly smart since they, now, comprise multi-tasking devices that can perform many tasks and computations. In addition, they are also equipped with a myriad of useful applications and high-speed data communication capabilities (e.g., an internet access, texting, e-mail, apps, audio/video recorders, and modern digital cameras). Indeed, Davies, 2015 as cited by Anshari et al., [6] claimed that a smartphone is a powerful handheld computer with an intrinsic connection mobile network.

Despite the amazing power, however, smartphone use in classrooms leaves a controversy. In one hand it may facilitate learning but in the other end it may interfere it. Therefore, citing Lenhart (2012), Thomas, O'Bannon and Bolton [7] reported that the use of smartphones in many schools in US was once banned because of the perception that they were disruptive. However, considering the increased functionality of these powerful tools, many educators re-evaluated the ban and re-considered to have students benefit the smartphones in the classrooms. Further, they were more supportive reporting that among the benefits of allowing smartphones in the classrooms refer to the facts that they can be used for content creation, differentiation of instruction, and assessment. In addition, the portability of smartphones enables both teachers and students to access the course material anywhere at any time.

\section{METHODOLOGY}

\section{Sample}

Data were collected from 130 secondary school teachers who were randomly recruited. In so doing, a questionnaire of Academic Smartphone Use in classes of English as a Foreign Language (EFL) was posted in google form for one month and it got positive responses from teachers of both public schools $(80.3 \%)$ and private schools $(19.7 \%)$. Most of them $(27.3 \%)$ are female and the rest $(22.7 \%)$ are male teachers. They were deployed in three school clusters i.e., Junior Secondary or SekolahMenengahPertama - SMP (30.3\%), Vocational Senior Secondary or SekolahMenengahKejuruan - SMK (49.2\%), and General Senior Secondary Schools or SekolahMenengahUmum SMU (20.5\%). Most respondents (90.2\%) have been teaching for more than 10 years in the respective schools.

\section{Instrument}

To collect the data, as noted, a questionnaire of Academic Smartphone Use in EFL classes was constructed and applied. It consists of 4 key items asking for the following aspects, such as the practical use of smartphones (e.g., In addition to communicate, for what purposes do you use your smartphones?), delivery of language skills mediated by Apps (e.g., what language skills have you delivered using Apps in your smartphones?), academic use of smartphones for language assessment (e.g., what Apps do you apply to assess students skills in EFL classes?), smartphone use to motivate students to learn (e.g., how do you use your smartphones to motivate students to learn?).

The instrument has been qualitatively verified to ensure its validity. For this purpose, three subject matter experts
(SME's) involved. They possess more than adequate competence in applying digital tools to deliver teaching in EFL classes.

\section{RESULT}

1. Practical purposes of applying Apps by teachers in respective school clusters

All teachers in the three school clusters, SMP, SMK, and $S M U$, preferred to benefit their smartphones for the top three purposes, such as teaching media, searching for teaching materials, and searching for general information. Data are presented below.

\section{The Use of Smartphone by SMP Teachers}

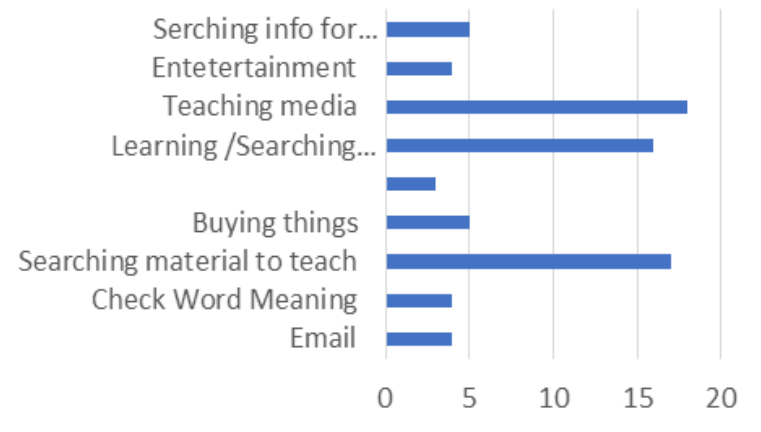

\section{The use of Smartphone by SMK} Teachers

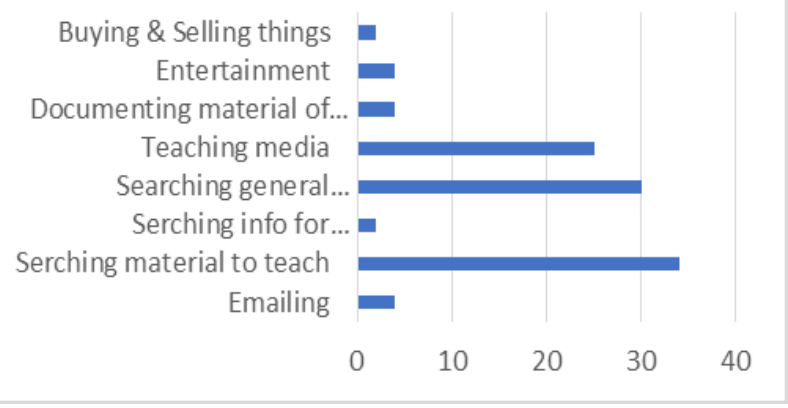

The Use of Smartphone by SMU Teachers

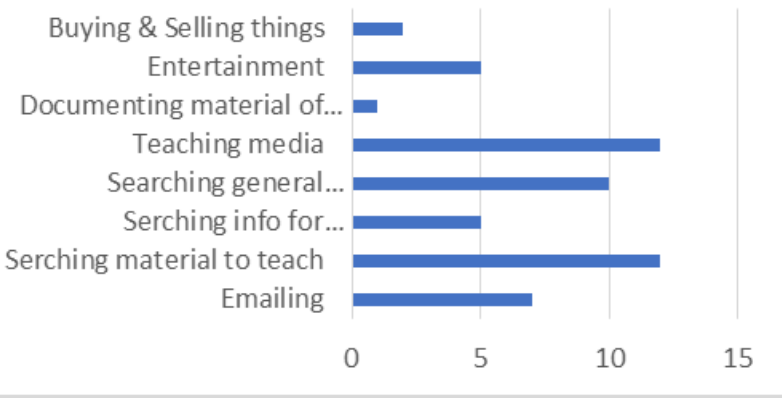

Published By: Blue Eyes Intelligence Engineering \& Sciences Publication 


\section{Use of smartphones to teach language skills}

All teachers in the three school clusters, SMP, SMK, and $S M U$, preferred to teach reading skills mediated by available Apps. Data are presented below.
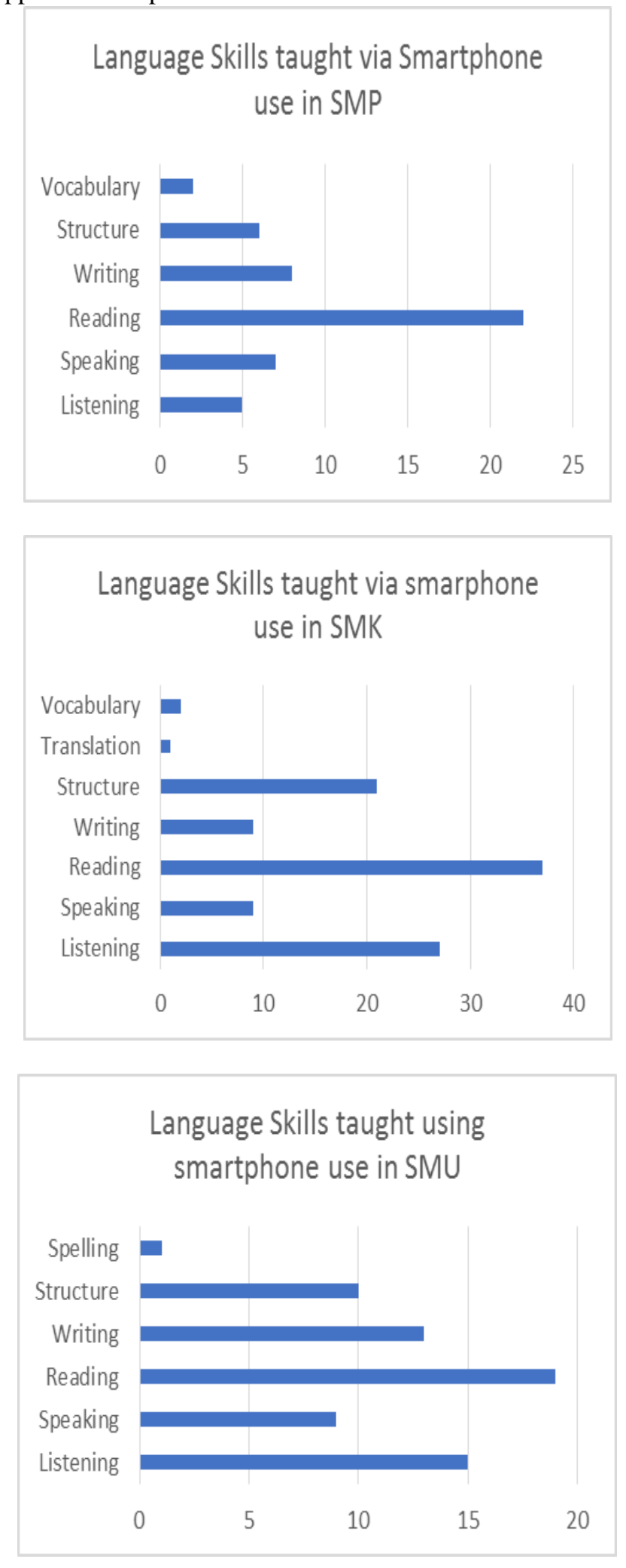

\section{Use of smartphones for classroom tests}

Teachers in SMK and SMU preferred to use Google application to deliver language tests in the classroom, but SMP teachers preferred audio recording. Data are presented below.
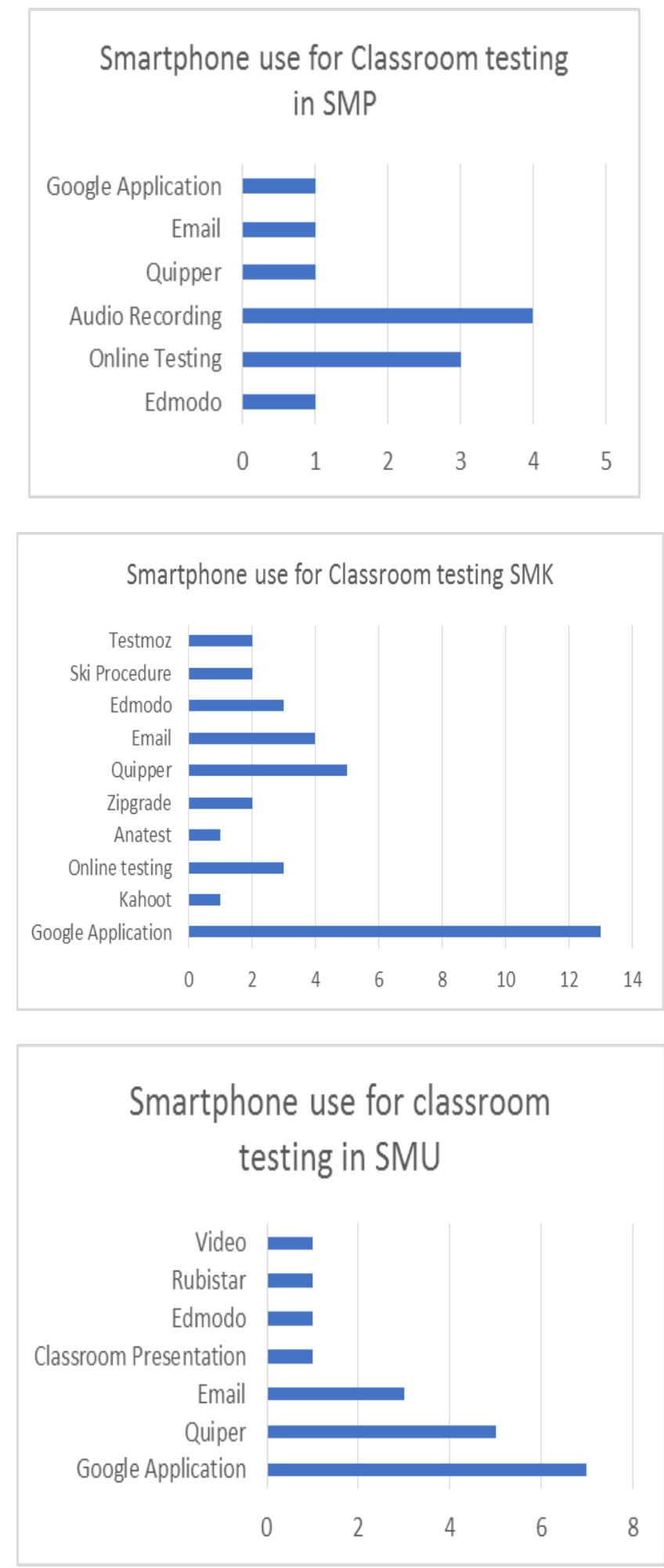

\section{Smartphone use to motivate students to learn}

To motivate students to learn, teachers have different ways as far as smartphone use is concerned e.g., most SMP teachers preferred to ask students to benefit available Apps and web links, SMK teachers preferred to ask students to watch films or videos, and SMU teachers preferred to facilitate students with various links. Data are presented below.

Published By

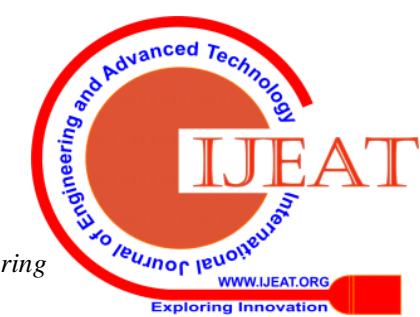




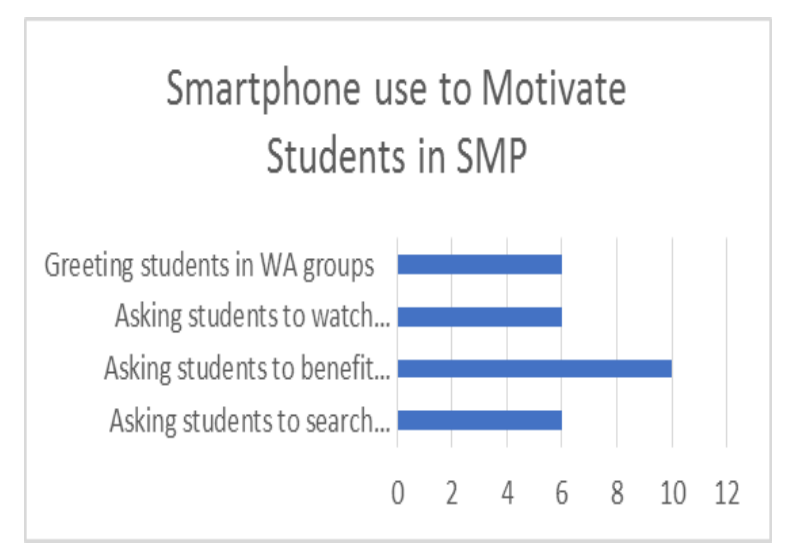

\section{Smartphone use to Motivate Students in SMK}

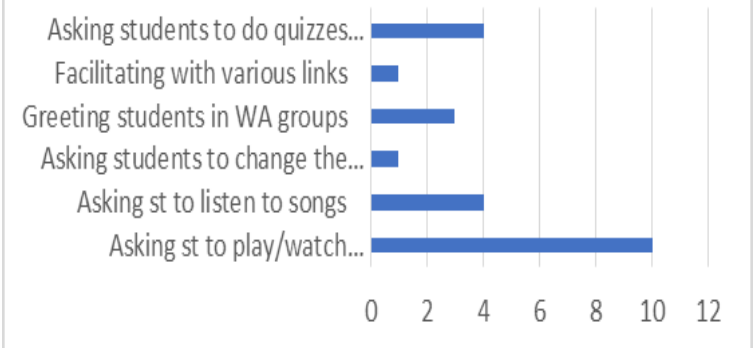

\section{Smartphone use to motivate students in SMU}

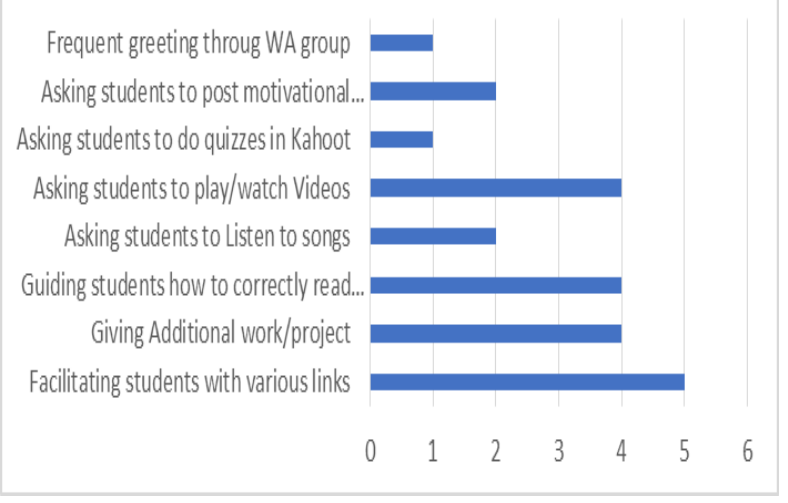

\section{CONCLUSION}

Several points are necessarily important to conclude as far as academic smartphone use is concerned.

1. EFL teachers have utilized the available Apps to blend the teaching deliveries as well as testing administration. This proves that the smartphones, at schools, have been purposefully applied for academic activities.

2. Reading is the most preferred skills to teach using smartphones although kinds of Apps vary from teachers to teachers in the three school clusters.

3. In administering classroom tests using smartphones, google application is preferred.

4. Motivating students to learn can be continuously promoted by means of smartphone use. In this research all teachers have applied it.
5. Rule reinforcement is urgently required to ensure that the smartphone use is purposefully utilized for academic activities.

\section{DISCUSSION}

Regarding the conclusion as pointed above, it's advisable that parents should no longer worry very much with the smartphones in the hands of their children during the school hours. This is possible as teachers at schools have benefited the smartphones for classroom activities. In addition, rule reinforcement has also been enacted. However, at homes, it's best if they consent to let their children use the smartphone purposefully under a clear arrangement. When necessary, proper rules and occasional controls may be applied. This is unavoidable as it is quite evident that overuse of smartphones is problematic that may result in numerous negative consequences in daily life [8], [9].

It's evident that reading is one among other language skills preferred by teachers to deliver by means of smartphones. Such is not surprising as ample researches reported that students found it easier and more fun to learn reading skills which is mediated by means of smartphone application. In addition, integration of smartphone application can leverage motivation and interest, but not confidence, in learning foreign languages in general including reading skills [10], [11].

However, in a broader sense, this likely needs thoughtful attention that some other language skills may also be delivered by means of the advanced technology, such as the smartphones.

In addition to the above, an additional item was inserted in the questionnaire. It probed respondent's suggestion (i.e., Do you have any suggestion how to optimize smartphones for academic use?). Three groups of suggestion arose, i.e., technical, managerial and abstain responses. Most respondents suggested some technical matters which was likely utopian, such as that special Apps for English learning should be created. Another technicality concerned the teacher's skills and competences in utilizing smartphones for learning which need improvement. In this concern, they hoped to get special trainings. Other suggestions concerned the managerial aspects, particularly focusing on the rule enforcement as far as smartphone use during school hours was concerned. This consisted of two kinds, i.e., soft execution such as limitation of smartphone use at schools, and hard sanction to totally ban the use of smartphone under any circumstance. The last group belonged to those who stayed abstain. This, however, didn't mean they had no ideas but, rather, they likely felt no need to raise any suggestion since their schools had prohibited students to bring along the phones to schools. In other words, the last group likely agrees with those who put suggestions to totally ban the use of smartphones at schools. This proves that teachers have put high concern with the smartphone use at schools. They are very cautious that the smartphone use at schools should be set purposefully for academic concerns. Data is presented below.

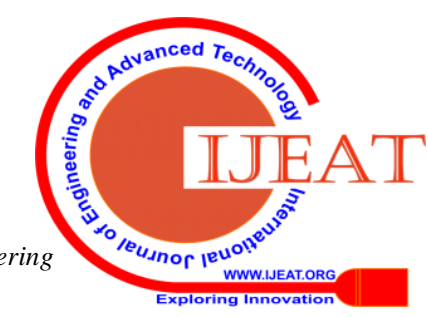




\section{REFERENCES}

1. emarketer.

Available

from

(https://id.techinasia.com/jumlah-pengguna-smartphonedi-indonesia-2018).

2. Asian Parent Insight. Available from (https://id.theasianparent.com/hasil-survey-smartphoneyang-mengejutkan/web-view/).

3. Muhammad, A. A. The Impact of Mobiles on Language Learning on the Part of English Foreign Language (EFL) University Students. Procedia - Social and Behavioral Sciences, 136, 104-108. https://doi.org/10.1016/j.sbspro.2014.05.297.

4. Ng, S. F., Nor, N. H. M., Hassan, N. S. Oi. C., \&Malek, N. A. A. The Relationship Between Smartphone Use and Academic Performance: A Case of Students in a Malaysian Tertiary Institution, January 2017. Available from https://www.researchgate.net/publication/320280702.

5. Genc, Z. Parents' Perceptions about the Mobile Technology Use of Preschool Aged Children. Procedia Social and Behavioral Sciences, 146, pp. 55-60, August 2014. https://doi.org/10.1016/i.sbspro.2014.08.086.

6. Anshari, M. Almunawar, M. N., Shahrill, M., Wicaksono, D. K., Islam, U., \& Sharif, S. Smartphones usage in the classrooms: Learning aid or interference? Education and Information Technologies: The Official Journal of the IFIP Technical Committee on Education, Vol 22, Number 6, pp. 3063 - 3079, Jan 2017.

7. Thomas, K. M., O’Bannon, B. W., Bolton, N., Cell Phones in the Classroom: Teachers ' Perspectives of Inclusion, Benefits, and Barriers, Computers in the Schools, (C) Taylor \& Francis Group, LLC Vol. 30, pp. 295-308, 2013, Dec. 2013.

8. van, Velthoven, M. H., Powell, J., \& Powel, G. Problematic smartphone use: Digital approaches to an emerging public health problem, Digital Health volume 4, pp. 1-9, 2018.

9. Campbell, M. A. The impact of the mobile phone on young people's social life, Social Change, pp. 1-14, Oct, 205.

10. Chee, K., Yahaya, N. \& Ibrahim, N., Effectiveness of mobile learning application in improving reading skills in Chinese language and towards post-attitudes, Intl. J. Mobile Learning and Organisation, Vol. 11, No. 3, pp. 210-225, 2017.

11. Nalliveettil, G. M., \&Alenazi, T. H. K., The Impact of Mobile Phones on English Language Learning : Perceptions of EFL Undergraduates, Journal of Language Teaching and Research, Vol. 7, No. 2, pp. 264-271, March 2016 